\title{
Prognostic significance of TRAIL death receptors in Middle Eastern colorectal carcinomas and their correlation to oncogenic KRAS alterations
}

\author{
Prashant Bavi ${ }^{1}$, Sarita E Prabhakaran ${ }^{1}$, Jehad Abubaker ${ }^{1}$, Zeeshan Qadri ${ }^{1}$, Thara George ${ }^{1}$, Nasser Al-Sanea ${ }^{3}$, \\ Alaa Abduljabbar', Luai H Ashari ${ }^{3}$, Samar Alhomoud ${ }^{3}$, Fouad Al-Dayel, Azhar R Hussain', Shahab Uddin', \\ Khawla S Al-Kuraya ${ }^{1 *}$
}

\begin{abstract}
Background: Tumour necrosis factor-related apoptosis-inducing ligand (TRAIL) is a member of the tumour necrosis factor cytokine family that induces apoptosis upon binding to its death domain containing receptors, TRAIL receptor 1 (DR4) and TRAIL receptor 2 (DR5). Expression of TRAIL receptors is higher in colorectal carcinoma (CRC) as compared to normal colorectal mucosa and targeted therapy with TRAIL leads to preferential killing of tumor cells sparing normal cells.

Methods: We investigated the expression of TRAIL and its receptors in a tissue microarray cohort of 448 Middle Eastern CRC. We also studied the correlation between TRAIL receptors and various clinico-pathological features including key molecular alterations and overall survival.

Results: CRC subset with TRAIL-R1 expression was associated with a less aggressive phenotype characterized by early stage $(p=0.0251)$ and a histology subtype of adenocarcinomas $(p=0.0355)$. Similarly CRC subset with TRAILR2 expression was associated with a well-differentiated tumors $(p<0.0001)$, histology subtype of adenocarcinomas $(p=0.0010)$ and tumors in left colon $(p=0.0009)$. Over expression of pro apoptotic markers: $p 27^{\text {KIP1 }}$ and KRAS4A isoforms was significantly higher in CRC subset with TRAIL-R1 and TRAIL-R2 expression; TRAIL-R1 expression was also associated with cleaved caspase-3( $p=0.0011)$. Interestingly, TRAIL-R2 expression was associated with a microsatellite stable (MS-S/L) phenotype $(p=0.0003)$ and with absence of KRAS mutations $(p=0.0481)$.

Conclusion: TRAIL-R1 expression was an independent prognostic marker for better survival in all CRC samples and even in the CRC group that received adjuvant therapy. The biological effects of TRAIL in CRC models, its enhancement of chemosensitivity towards standard chemotherapeutic agents and the effect of endogenous TRAIL receptor levels on survival make TRAIL an extremely attractive therapeutic target.
\end{abstract}

\section{Introduction}

Colorectal Cancer (CRC) is a major cause of mortality and morbidity worldwide. In Saudi Arabia, the incidence of CRC is increasing. According to the latest statistics, $\mathrm{CRC}$ is the second most common cancer among Saudi males and the third most common among Saudi females [1]. Currently available therapeutic approaches for CRC are less effective, and thus the prognosis is poor. Despite

\footnotetext{
* Correspondence: kkuraya@kfshrc.edu.sa

'Department of Human Cancer Genomic Research, MBC 98-16,Research Centre at KFNCCC, King Faisal Specialist Hospital and Research Centre,PO Box 3354, Riyadh 11211,Kingdom of Saudi Arabia

Full list of author information is available at the end of the article
}

a growing number of publications about biomarkers that give information on disease outcome, the best prognostic factors are still simple clinical parameters like number of lymph nodal metastasis, presence of distant metastasis, tumour grade and AJCC stage. Prognostic biomarkers might especially be useful for hypothesis testing for their relevance as predictive markers, as targets for therapy and for the selection of patients for adjuvant treatment [2].

Apoptosis, or programmed cell death, is a major control mechanism by which cells die if DNA damage is not repaired [3]. Apoptosis is an essential biochemical

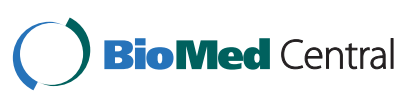

(c) 2010 Bavi et al; licensee BioMed Central Ltd. This is an Open Access article distributed under the terms of the Creative Commons Attribution License (http://creativecommons.org/licenses/by/2.0), which permits unrestricted use, distribution, and reproduction in any medium, provided the original work is properly cited. 
pathway for normal tissue homeostasis, cellular differentiation, and development. Derangements of normal apoptotic mechanisms provide a growth advantage to cancer cells [4]. The understanding of apoptosis has provided the basis for novel targeted therapies that can induce death in cancer cells or sensitize them to established cytotoxic agents and radiation therapy [5]. In addition, as apoptosis usually does not elicit host inflammatory or immune response, this type of cell death is the preferred way of cancer cell killing by various treatments. Accordingly, selectively inducing apoptosis in tumour cells is gaining recognition as a promising therapeutic approach for many cancers [6]. Tumour necrosis factor-related apoptosis-inducing ligand (TRAIL or Apo2 ligand) is a member of the tumour necrosis factor (TNF) cytokine family that induces apoptosis upon binding to its death domain containing receptors, TRAIL receptor 1 (death receptor 4, DR4) and TRAIL receptor 2 (death receptor 5, DR5) [7]. The TRAIL receptors, TRAIL-R1 and TRAIL-R2, are highly expressed in many cancer cells including CRC [8-10]. A further three TRAIL receptors exist, which are unable to induce apoptosis and act as decoys. Decoy receptors 1 (DcR1) and 2 (DcR2), similar to TRAIL-R1 and TRAIL-R2, are expressed on the cell surface. Thus, overexpression of either DcR1 or DcR2 confers protection against TRAIL-induced apoptosis $[11,12]$. The fifth TRAIL receptor is osteoprotegerin (OPG), a secreted, low affinity receptor for TRAIL $[11,12]$. Binding of TRAIL to TRAIL-R1 and TRAIL-R2 induces trimerization of TRAIL-R1 and TRAIL-R2 [13]. The trimerized TRAIL-R1 and TRAIL-R2 bind to FADD, which recruits caspase 8 and initiates a proteolysis cascade that eventually leads to cell death by apoptosis. Many cancer cells are resistant to death receptor induced apoptosis [4]. The mechanisms of resistance include the presence of decoy receptors for TRAIL [12], the loss of TRAIL receptor expression [14], the overexpression of inhibitory proteins in signal transduction pathways such as FLICE-inhibitory protein [14], and the mutation of TRAIL-R2 gene [15-18].

Oncogenic mutations such as ras may enhance expression of TRAIL receptors; potentially sensitizing these tumors to TRAIL based therapies [19-21]. Constitutively activated Ras increases the tumorigenic potential of cells because it causes deregulation of important intracellular signaling pathways [22]. Activated RAS mediates its biological activity through interaction with various downstream effector targets, thus activating pathways like MEK, PI3K, and Rho GTPases [22,23]. RAS regulates a RAF-MEK-ERK1/2 kinase cascade and this pathway is found to be active in human colon adenocarcinomas cells [24] as well as in human colorectal tumors [25]. Drosopoulos et al. [21] have shown transformation of the colon cell line Caco- 2 by ras oncogenes sensitizes these cells to TRAIL induced apoptosis by causing specific MEK-dependent up-regulation of TRAIL-R1 and TRAIL-R2. Nesterov A et al. [20] have demonstrated that normal cells are sensitized to TRAIL when TRAIL$\mathrm{R} 2$ is up regulated by overexpression of c-myc or oncogenic ras mutants. Thus, RAS-MEK-ERK1/2 signaling pathway can sensitize cells to TRAIL-induced apoptosis by up-regulating TRAIL-R1, TRAIL-R2 and TRAILbased therapeutic strategies using TRAIL agonists could be used in cases of human colon cancers bearing RAS mutations. Therefore, we also sought to explore the potential link between expression of TRAIL and its receptors with KRAS alterations in CRC.

The aims of the present study were: $(a)$ to determine the TRAIL/TRAIL receptor expression pattern in normal and neoplastic colon epithelium; $(b)$ to correlate immunohistochemical expression patterns with KRAS alterations, microsatellite instability and pro apoptotic markers; (c) to correlate immunohistochemical expression patterns with overall survival.

\section{Results \\ Expression of TRAIL and its receptors TRAIL-R1 and TRAIL-R2}

Incidence of TRAIL-R1, TRAIL-R2 and TRAIL ligand expression in CRC was 85.5\% (331/387), 59.4(217/365) and $31.5 \%(127 / 403)$ respectively [Figure 1]. These incidences are within the wide ranges reported earlier TRAIL: $37.5 \%$ to $83 \%$, TRAIL-R1:58.1\% to $100.0 \%$ and TRAIL-R2: $40.3 \%$ to $100 \%$ [26-31]. Incidence of noninterpretable tumor spots for TRAIL, TRAIL-R1 and TRAIL R2 ranged from 10 to $18 \%$. Tumor spots were deemed not interpretable if they had insufficient tumor cells, loss of tissue in the spot, or an abundance of necrotic tissue. Expression of TRAIL and its receptors was also evaluated in colorectal adenomas and adjacent colorectal mucosa [Figure 2]. Both TRAIL-R1 and TRAIL-R2 expression was significantly higher in both colorectal adenomas [TRAIL-R1 96.11 \pm 78.82 $(\mathrm{p}=0.0312)$; TRAIL-R2 $59.17 \pm 49.69(\mathrm{p}=0.0027)]$ and carcinoma [TRAIL-R1 $173.91 \pm 61.20(\mathrm{P}<0.00001)$; TRAIL-R2 $115.63 \pm 95.76(\mathrm{p}=<0.0001)]$ as compared to normal colorectal mucosa (TRAIL-R1 $52.13 \pm 42.48$; TRAIL-R2 $24.57 \pm 38.77$ ). In addition, there was a significant difference in expression of both TRAIL-R1 $(\mathrm{p}=0.0006)$ and TRAIL-R2 $(\mathrm{p}=<0.0001)$ between colorectal adenomas and carcinoma [Figure $3 \mathrm{~B}$ and $3 \mathrm{C}$ ]. Similarly, TRAIL expression was significantly higher in carcinoma (132.87 $\pm 64.23 ; \mathrm{p}<0.0001)$ and adenomas $(129.01 \pm 38.59 ; \mathrm{p}<0.0001)$ as compared to normal colorectal mucosa $(48.59 \pm 66.07)$. However, there was no difference in TRAIL expression between adenomas and carcinomas ( $p=0.6822$; Figure $3 \mathrm{~A})$. Thus the TRAIL system may play a key role in colorectal carcinogenesis. 


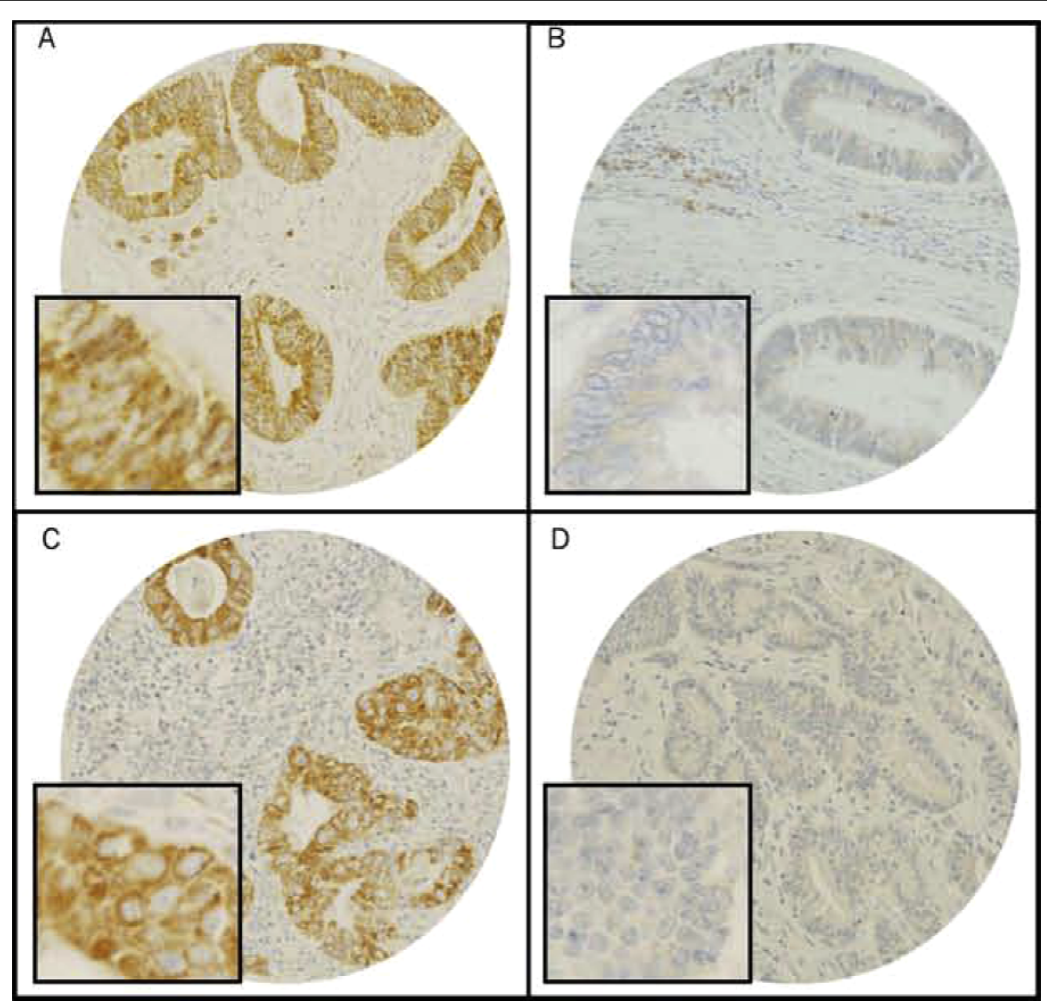

Figure 1 Tissue microarray-based immunohistochemical analysis of TRAIL receptors TRAIL-R1 and TRAIL-R2 in CRC patients. CRC array spots showing overexpression of TRAIL-R1 (A) and TRAIL-R2 (C). In contrast, other CRC tissue array spots showing low expression of TRAIL-R1 (B) and TRAIL-R2 (D). 20 ×/0.70 objective on an Olympus BX 51 microscope (Olympus America Inc, Center Valley, PA, USA), with the inset showing a $40 \times / 0.85$ aperture magnified view of the same

\section{Association of TRAIL, TRAIL-R1 and TRAIL-R2 with clinico-pathological parameters}

TRAIL-R1 was associated with histology subtype of adenocarcinomas $(\mathrm{p}=0.0355)$, early AJCC stage $(\mathrm{p}=$ 0.0251 ) and a trend of higher expression was noted with well-differentiated tumors $(\mathrm{p}=0.0887$ ). No association was seen with age, gender and tumor site (Table 1). Similarly, TRAIL-R2 was associated with histology subtype of adenocarcinomas $(\mathrm{p}=0.0010$, tumors in the left colon $(\mathrm{p}=0.0009)$ and a significantly higher expression was noted with well-differentiated tumors ( $p<0.0001)$. No associations were seen with age, gender and tumor stage (Table 2). TRAIL ligand expression was not associated with any of the clinico-pathological parameters (see Additional File 1 Table S1).

\section{Association of TRAIL, TRAIL-R1 and TRAIL-R2 with KRAS mutations and KRAS splice variants KRAS4A and KRAS4B}

TRAIL-R2 expression was significantly higher in the CRC subset lacking KRAS mutations as compared to CRC with KRAS mutations ( $p=0.0481$; Figure 4$)$. Interestingly, both TRAIL-R1 ( $\mathrm{p}<0.0001)$ and TRAIL-R2(p < 0.0001 ) showed a highly significant association with the pro-apoptotic KRAS4A isoform. However, TRAIL-R1 expression did not show any correlations with KRAS mutations and KRAS4B isoform (Table 1 \&2). TRAIL expression did not show any associations with KRAS mutations or expression of KRAS splice variants (see Additional File 1 Table S1).

\section{Associations of TRAIL, TRAIL-R1 and TRAIL-R2 with} microsatellite instability, cleaved caspase 3 and p2 $27^{\text {kip } 1}$ p27 ${ }^{\text {kip } 1}$ expression was significantly associated with both TRAIL-R1 ( $\mathrm{p}=0.0024)$ and TRAIL-R2 ( $\mathrm{p}<0.0001$; Table 1 \&2). CRC with expression of TRAIL-R1 but not TRAIL-R2 or TRAIL also showed expression of cleaved caspase $3(\mathrm{p}=0.0011)$. Although TRAIL-R2 was associated with a phenotype of microsatellite stable (MSI$\mathrm{S} / \mathrm{L})$ tumors $(\mathrm{p}=0.0003)$, no associations were seen between TRAIL-R1 or TRAIL and microsatellite instability status.

\section{Overall survival in all patients, selected stage subgroups} and combination groups of TRAIL receptors

CRC with low TRAIL-R1 expression also showed a poor 5 year overall survival of $53.9 \%$ as compared to $68.1 \%$ with high TRAIL-R1 expression ( $\mathrm{p}=0.0124$; Figure 5A). Similarly, CRC with low TRAIL-R2 expression also 


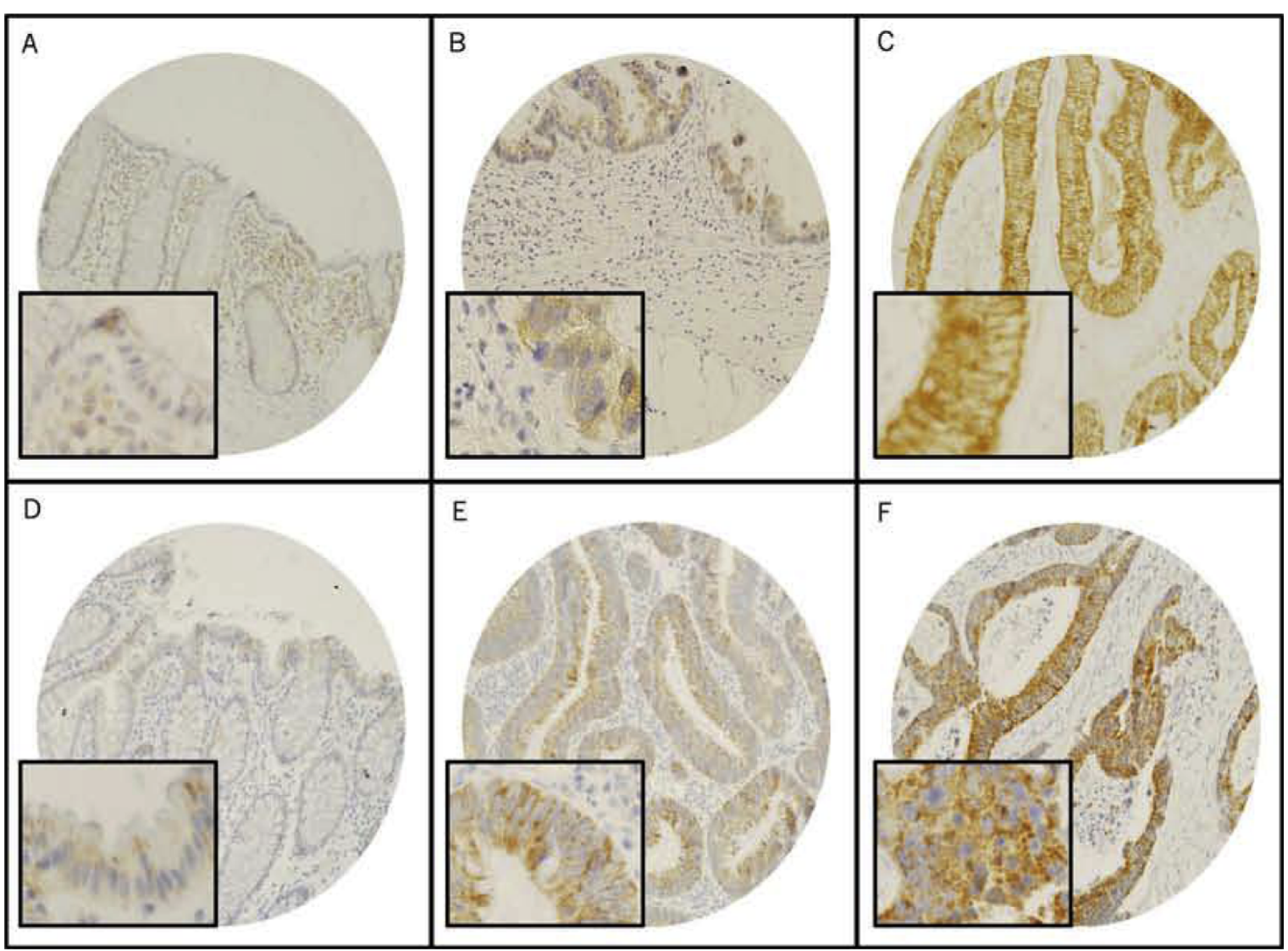

Figure 2 Tissue microarray-based immunohistochemical analyses of TRAIL receptors TRAIL-R1 and TRAIL-R2 in CRC carcinogenesis. A progressive increase on TRAIL-R1 expression was seen from normal colorectal mucosa (A) to adenoma (B) to carcinoma(C). Similarly, a progressive increase on TRAIL-R2 expression was seen from normal colorectal mucosa (D) to adenoma (E) to carcinoma (F).

showed a poor 5 year overall survival of $57.6 \%$ as compared to $67.3 \%$ with high TRAIL-R2 expression ( $\mathrm{p}=$ 0.0211; Figure 5B). TRAIL expression did not show any prognostic significance $(\mathrm{p}=0.2901)$. To exclude that the observed prognostic difference were caused by classical prognostic factors of CRC, we performed a multivariate analysis (Cox proportional hazards) with histological subtype, tumor grade, tumor stage, age, gender and microsatellite instability status as variables (Table 3 ). In the multivariate analysis, only TRAIL-R1 expression retained its significance. The relative risk was 1.84 (for low TRAIL-R1 expression (95\% CI $1.10-3.02$; p = $0.0273)$ and 6.56 for high stage group III-IV (95\% CI 3.67- 12.78; $\mathrm{p}=<0.0001)$. Thus, TRAIL-R1 was an independent prognostic marker in Middle Eastern Colorectal Carcinoma. To exclude that TRAIL-R1 is not a readout of KRAS-4A or p27 we reanalyzed our data and did a Cox proportional hazards model where we included age, gender, Stage, Grade, KRAS-4A, p27 and TRAIL-R1 expression (see Additional File 1 Table S2). In a Cox proportional Hazards model, the independent prognostic significance of TRAIL-R1 was weakened $(\mathrm{p}=$
0.0883). However, AJCC stage, p27 and KRAS4A still remained independent prognostic markers.

Although TRAIL-R1 expression was significantly more in early stage tumors, a vast majority of Stage III \& IV tumors $(82 \%)$ also showed TRAIL-R1 expression. Both TRAIL-R1 ( $\mathrm{p}=0.0060)$ and TRAIL-R2 $(\mathrm{p}=0.0263)$ were associated with better outcome only in the advanced Stage group (III and IV; see Additional File 2). When stage II and III were taken together only TRAIL-R2 expression was associated with better overall survival ( $\mathrm{p}=0.0088)$; TRAIL-R1 expression was not significant $(\mathrm{p}=0.2508$; see Additional File 3). Co-expression of TRAIL-R1 and TRAIL-R2 was seen in $56.85 \%$ of the CRC( $191 / 336)$ and was associated with a good survival $(p=0.0107$; see Additional File 4) which remained significant in multivariate analysis (Cox proportional hazards) with TRAIL-R1/R2 co-expression, tumor grade, tumor stage, age and gender as variables (see Additional File 1 Table S3).

TRAIL death receptors and response to adjuvant therapy The availability of 220 CRC from affected individuals who had undergone adjuvant therapy: chemotherapy 
Table 1 Clinico-pathological characteristics and TRAIL-R1 expression of patients with colorectal carcinoma

\begin{tabular}{|c|c|c|c|c|c|c|c|}
\hline & \multirow[b]{2}{*}{$\mathbf{N}$} & \multirow[b]{2}{*}{$\%$} & \multicolumn{2}{|c|}{$\begin{array}{c}\text { High } \\
\text { TRAIL-R1 }\end{array}$} & \multicolumn{2}{|c|}{$\begin{array}{c}\text { Low } \\
\text { TRAIL-R1 }\end{array}$} & \multirow[t]{2}{*}{$p$ value } \\
\hline & & & $\mathrm{N}$ & $\%$ & $\mathrm{~N}$ & $\%$ & \\
\hline Total Number of Cases & 387 & & 331 & 85.5 & 56 & 14.5 & \\
\hline \multicolumn{8}{|l|}{$\overline{\text { Age }}$} \\
\hline$<=50$ years & 126 & 32.6 & 110 & 87.3 & 16 & 12.7 & 0.4870 \\
\hline$>50$ years & 261 & 67.4 & 221 & 84.7 & 40 & 15.3 & \\
\hline \multicolumn{8}{|l|}{ Gender } \\
\hline Male & 193 & 49.9 & 167 & 86.5 & 26 & 13.5 & 0.5773 \\
\hline Female & 194 & 50.1 & 164 & 84.5 & 30 & 15.5 & \\
\hline \multicolumn{8}{|l|}{ Tumour Site } \\
\hline Left colon & 324 & 83.7 & 276 & 85.2 & 48 & 14.8 & 0.6576 \\
\hline Right colon & 63 & 16.3 & 55 & 87.3 & 8 & 12.7 & \\
\hline
\end{tabular}

\section{Histological Type}

$\begin{array}{llllllll}\text { Adenocarcinoma } & 334 & 86.3 & 291 & 87.1 & 43 & 12.9 & 0.0355\end{array}$

$\begin{array}{lllllll}\text { Mucinous Carcinoma } & 53 & 13.7 & 40 & 75.5 & 13 & 24.5\end{array}$

Tumour Stage

$\begin{array}{lrrrrrrr}\text { I } & 55 & 15.0 & 53 & 96.4 & 2 & 3.6 & 0.0251 \\ \text { II } & 126 & 34.2 & 105 & 83.3 & 21 & 16.7 & \\ \text { III } & 141 & 38.3 & 121 & 85.8 & 20 & 14.2 & \\ \text { IV } & 46 & 12.5 & 36 & 78.3 & 10 & 21.7 & \end{array}$

\section{Differentiation}

Well

Moderate

$\begin{array}{llllll}284 & 73.4 & 247 & 87.0 & 37 & 13.0\end{array}$

C

C $300-$ Cancer Vs Normal $<0.0001$

Normal Vs Adenoma $=0.0027$
Cancer Vs Adenoma $<0.0001$

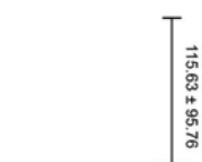

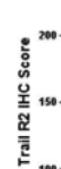

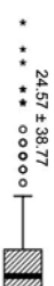

דיa
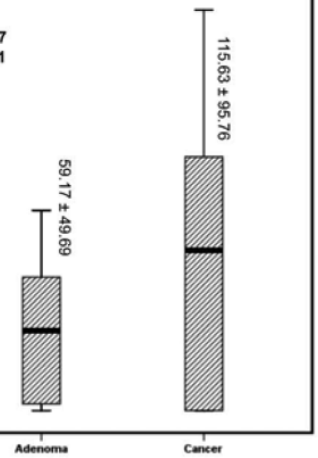

Figure 3 Box plot of TRAIL, TRAIL-R1 and TRAILR2 expression in cancer, adenoma, and normal samples of colorectal patients. (A) Using Student's t-test, the mean \pm SD of TRAIL expression in normal colorectal mucosa $(48.59 \pm 66.07)$, adenoma (129.01 \pm 38.59) and cancer (132.87 \pm 64.23$)$ and showed a significant association with cancer versus normal $(p<0.0001)$ and adenoma versus normal ( $p<0.0001)$. (B) Using Student's t-test, the mean \pm SD of TRAIL-R1 expression in normal colorectal mucosa (52.13 \pm 42.48), adenoma (96.11 \pm 78.82), cancer (173.91 \pm 61.20$)$ showed a significant association with cancer versus normal ( $p<0.0001$ ), adenoma versus $\operatorname{normal}(p=0.0312)$ and adenoma versus cancer $(p=0.0006)$. (C) Using Student's t-test, the mean \pm SD of TRAIL-R2 expression in normal colorectal mucosa $(24.57 \pm 38.77)$, adenoma (59.17 \pm 49.69$)$ and cancer $(115.63 \pm 95.76)$ showed a significant association with cancer versus normal ( $p<0.0001)$, adenoma versus normal $(p=$ $0.0027)$ and adenoma versus cancer $(p<0.0001)$
Poor

\begin{tabular}{lrrrrrrr} 
Poor & 70 & 18.1 & 54 & 77.1 & 16 & 22.9 & \\
\hline $\begin{array}{l}\text { KRAS Mutation } \\
\text { Present }\end{array}$ & 75 & 28.3 & 67 & 89.3 & 8 & 10.7 & 0.7407 \\
Absent & 190 & 71.7 & 167 & 87.9 & 23 & 12.1 & \\
\hline K-RAS 2A & & & & & & & \\
High expression & 155 & 46.7 & 150 & 96.8 & 5 & 3.2 & $<.0001$ \\
Low expression & 177 & 53.3 & 142 & 80.2 & 35 & 19.8 & \\
\hline Cleaved-Caspase 3 & & & & & & & \\
High expression & 172 & 49.9 & 160 & 93.0 & 12 & 7.0 & 0.0011 \\
Low expression & 173 & 50.1 & 141 & 81.5 & 32 & 18.5 & \\
\hline P27 (Nuc) & & & & & & & \\
High expression & 139 & 38.4 & 130 & 93.5 & 9 & 6.5 & 0.0024 \\
Low expression & 223 & 61.6 & 185 & 83.0 & 38 & 17.0 & \\
\hline MSI-Molecular & & & & & & & \\
MSI-H & 67 & 18.7 & 56 & 83.6 & 11 & 16.4 & 0.4731 \\
MSI-S/L & 292 & 81.3 & 254 & 87.0 & 38 & 13.0 & \\
\hline Overall Survival & & & & & & & \\
5 Years & & & & 68.1 & & 53.9 & 0.0124 \\
\hline
\end{tabular}

and/or radiotherapy, allowed us to investigate the possible impact of TRAIL-R1 on response to adjuvant therapy. For this analysis, we first stratified the individuals into two groups: (i) CRC patient who have received adjuvant therapy $(n=220)$, and (ii) CRC patient who have been treated by surgical resection only and have not received adjuvant therapy $(\mathrm{n}=90)$. There was a 
Table 2 Clinico-pathological characteristics and TRAIL-R2 expression of patients with colorectal carcinoma

\begin{tabular}{|c|c|c|c|c|c|c|c|}
\hline & \multirow[b]{2}{*}{$\mathbf{N}$} & \multirow[b]{2}{*}{$\%$} & \multicolumn{2}{|c|}{$\begin{array}{c}\text { High } \\
\text { TRAIL-R2 }\end{array}$} & \multicolumn{2}{|c|}{$\begin{array}{c}\text { Low } \\
\text { TRAIL-R2 }\end{array}$} & \multirow[t]{2}{*}{$p$ value } \\
\hline & & & $\mathrm{N}$ & $\%$ & $\mathrm{~N}$ & $\%$ & \\
\hline Total Number of Cases & 365 & & 217 & 59.4 & 148 & 40.6 & \\
\hline \multicolumn{8}{|l|}{ Age } \\
\hline$<=50$ years & 121 & 33.1 & 71 & 58.7 & 50 & 41.3 & 0.8320 \\
\hline$>50$ years & 244 & 66.9 & 146 & 59.8 & 98 & 40.2 & \\
\hline \multicolumn{8}{|l|}{ Gender } \\
\hline Male & 172 & 47.1 & 101 & 58.7 & 71 & 41.3 & 0.7883 \\
\hline Female & 193 & 52.9 & 116 & 60.1 & 77 & 39.9 & \\
\hline \multicolumn{8}{|l|}{ Tumour Site } \\
\hline Left colon & 309 & 84.7 & 195 & 63.1 & 114 & 36.9 & 0.0009 \\
\hline Right colon & 56 & 15.3 & 22 & 39.3 & 34 & 60.7 & \\
\hline \multicolumn{8}{|l|}{ Histological Type } \\
\hline Adenocarcinoma & 323 & 88.5 & 202 & 62.5 & 121 & 37.5 & 0.0010 \\
\hline Mucinous Carcinoma & 42 & 11.5 & 15 & 35.7 & 27 & 64.3 & \\
\hline \multicolumn{8}{|l|}{ Tumour Stage } \\
\hline । & 46 & 13.3 & 33 & 71.7 & 13 & 28.3 & 0.2842 \\
\hline$\|$ & 117 & 33.9 & 65 & 55.6 & 52 & 44.4 & \\
\hline III & 137 & 39.7 & 84 & 61.3 & 53 & 38.7 & \\
\hline IV & 45 & 13.0 & 28 & 62.2 & 17 & 37.8 & \\
\hline \multicolumn{8}{|l|}{ Differentiation } \\
\hline Well & 28 & 7.7 & 22 & 78.6 & 6 & 21.4 & $<0.0001$ \\
\hline Moderate & 276 & 75.6 & 176 & 63.8 & 100 & 36.2 & \\
\hline Poor & 61 & 16.7 & 19 & 31.1 & 42 & 68.9 & \\
\hline \multicolumn{8}{|l|}{ KRAS Mutation } \\
\hline Present & 67 & 29.9 & 41 & 61.2 & 26 & 38.8 & 0.0481 \\
\hline Absent & 157 & 70.1 & 117 & 74.5 & 40 & 25.5 & \\
\hline \multicolumn{8}{|l|}{ K-RAS 2A (cyto) } \\
\hline High expression & 160 & 46.8 & 128 & 80.0 & 32 & 20.0 & $<0.0001$ \\
\hline Low expression & 182 & 53.2 & 82 & 45.1 & 100 & 54.9 & \\
\hline \multicolumn{8}{|l|}{ Cleaved-Caspase 3} \\
\hline High expression & 164 & 49.8 & 109 & 66.5 & 55 & 33.5 & 0.1209 \\
\hline Low expression & 165 & 50.2 & 96 & 58.2 & 69 & 41.8 & \\
\hline \multicolumn{8}{|l|}{ P27 (Nuc) } \\
\hline High expression & 135 & 40.2 & 102 & 75.6 & 33 & 24.4 & $<0.0001$ \\
\hline Low expression & 201 & 59.8 & 105 & 52.2 & 96 & 47.8 & \\
\hline \multicolumn{8}{|l|}{ MSI-Molecular } \\
\hline MSI-H & 66 & 19.8 & 28 & 42.4 & 38 & 57.6 & 0.0003 \\
\hline MSI-S/L & 267 & 80.2 & 178 & 66.7 & 89 & 33.3 & \\
\hline \multicolumn{8}{|l|}{ Overall Survival } \\
\hline 5 Years & & & & 67.3 & & 57.6 & 0.0211 \\
\hline
\end{tabular}

statistically significant difference in survival between individuals with tumors with TRAIL-R1 overexpression versus those with reduced expression $(\mathrm{p}=0.0033$; see Additional File 5). To exclude that the observed prognostic difference was caused by classical prognostic factors of CRC we performed a multivariate analysis (Cox proportional hazards) with TRAIL-R1 expression, tumor grade, tumor stage, age and gender as variables (see Additional File 1 Table S4). We found that the prognostic value of TRAIL-R1 expression in adjuvant treated individuals was independent of these factors. Similarly, TRAIL-R2 expression was also associated with trend towards better outcome in the adjuvant treated CRC subgroup $(\mathrm{p}=0.0998)$ but no association with outcome was seen in the group which did not receive adjuvant therapy.

\section{Discussion}

We conducted this study to examine the relations of TRAIL and it receptors: TRAIL-R1 and TRAIL-R2 with clinical, pathologic, molecular characteristics and patient survival in Saudi colorectal cancers. Expression of TRAIL-R1 or TRAIL-R2 was associated with a less aggressive phenotype characterized by an early AJCC stage and well-differentiated tumors. TRAIL-R2 expression was associated with microsatellite stable phenotype and with absence of KRAS mutations. TRAIL-R1 but not TRAIL-R2 was an independent prognostic marker for better survival.

Using immunohistochemistry, we have studied the expression of TRAIL and its receptors in Saudi CRC; incidence of TRAIL R1, TRAIL-R2 and TRAIL expression was $85.5 \%, 59.4 \%$ and $31.5 \%$ respectively. In agreement with earlier studies, we have also observed a progressive increase in expression of TRAIL and its receptors: TRAIL-R1 and TRAIL-R2 in colorectal carcinoma and noted a strong association of TRAIL -R1 or TRAIL-R2 expression with differentiation and an early stage. The prognostic implication of TRAIL receptor expression is the subject of intensive investigation as malignant cells are more sensitive to TRAIL-induced apoptosis than their benign counterparts are and this potentially affects the future management of patients [32-34]. Furthermore, our data indicates that high TRAIL-R1 expression was an independent prognostic marker for better survival in Saudi CRC patients. TRAILR2 was also associated significantly with better outcome but failed to remain significant in multivariate analysis. TRAIL-R1 expression was also associated with better outcome in the following subgroups: Stage III and IV ( $\mathrm{p}$ $=0.0060$ ) and CRC subgroup who received adjuvant therapy $(p=0.0033)$. To elucidate the role of TRAIL expression further analysis was done in the following subgroup: CRC subgroup with high co-expression of TRAIL and TRAIL-R1 and CRC subgroup with high coexpression of TRAIL and TRAIL-R2. Both these combination groups were not associated with outcome (data not shown). Thus, TRAIL ligand co-expression with TRAIL receptors does not influence the outcome.

These findings are in agreement with earlier studies by Starter et al [26] where TRAIL-R1 expression was 


\section{A}

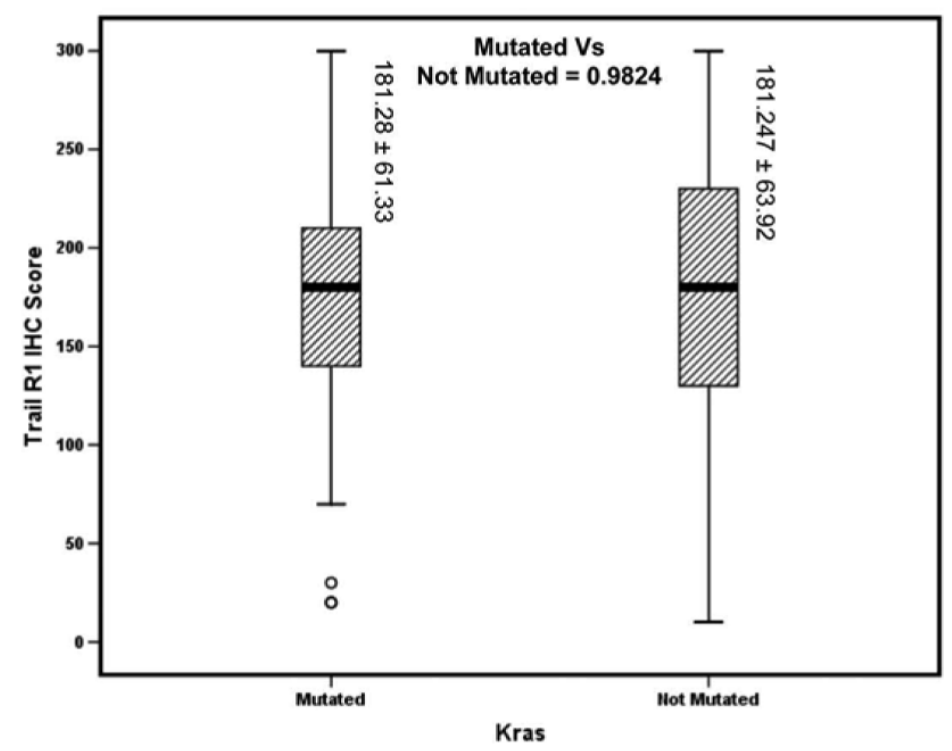

B

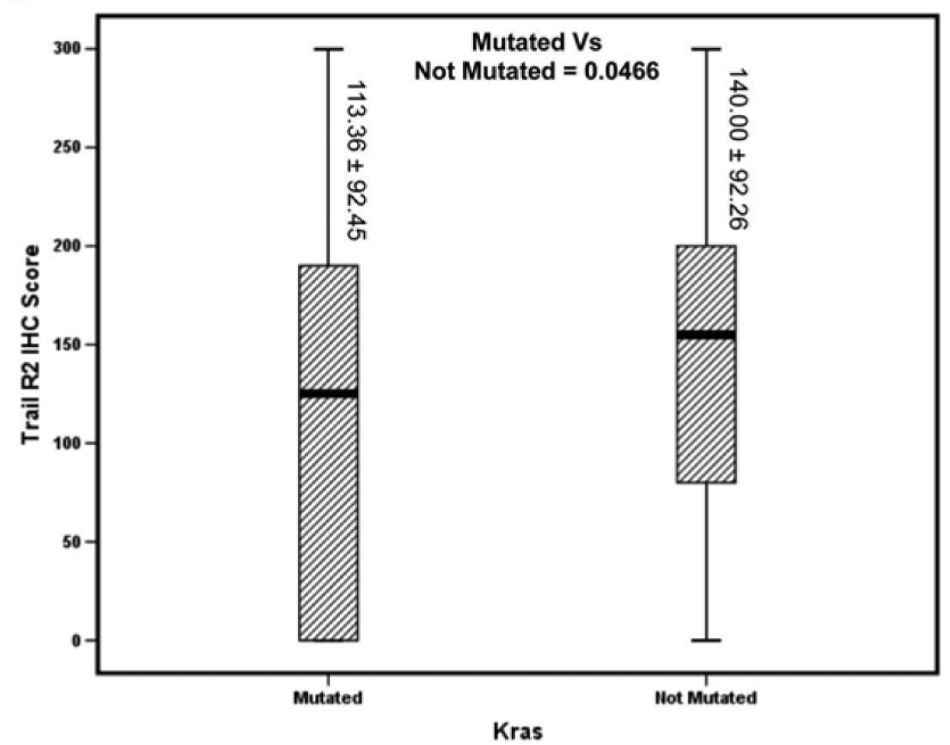

Figure 4 Box plot analysis of TRAIL-R1 and TRAIL-R2 expression in KRAS mutated versus non-mutated colorectal patients. (A) Using Student's t-test, the mean \pm SD of TRAIL-R1 expression in KRAS mutated (181.28 \pm 61.33 )and non mutated (181.25 \pm 63.92).However, this difference in expression was not statistically significant $(p=0.9824)$. (B Using Student's t-test, the mean \pm SD of TRAlL-R2 expression in KRAS mutated (113.36 \pm 92.45) and not mutated (140.00 \pm 92.26). There was statistically significant difference in expression $(p=0.0466)$.

associated with a better disease free survival in a cohort of 129 Stage II and III CRC [26]. Granci et al. [28] studied the TRAIL receptors TRAIL-R $1,-2,-3$ and -4 expression by immunohistochemistry in metastatic stage IV CRC and found that concomitant low/mediumTRAIL-R1 and high TRAIL-R3 expression in primary CRC is significantly associated with a poor response to
5-FU-based first-line chemotherapy and with a shorter progression-free survival. Surprisingly, high TRAIL R1 was associated with worse disease free survival and overall survival in 376 CRC patients with Stage III [30]. Ullenhag et al. [29] analyzed FLICE inhibitory protein (c-FLIP) and TRAIL receptors(TRAIL-R1 and R-2) in 476 CRC of all Stage groups(I to IV): Overexpression of 


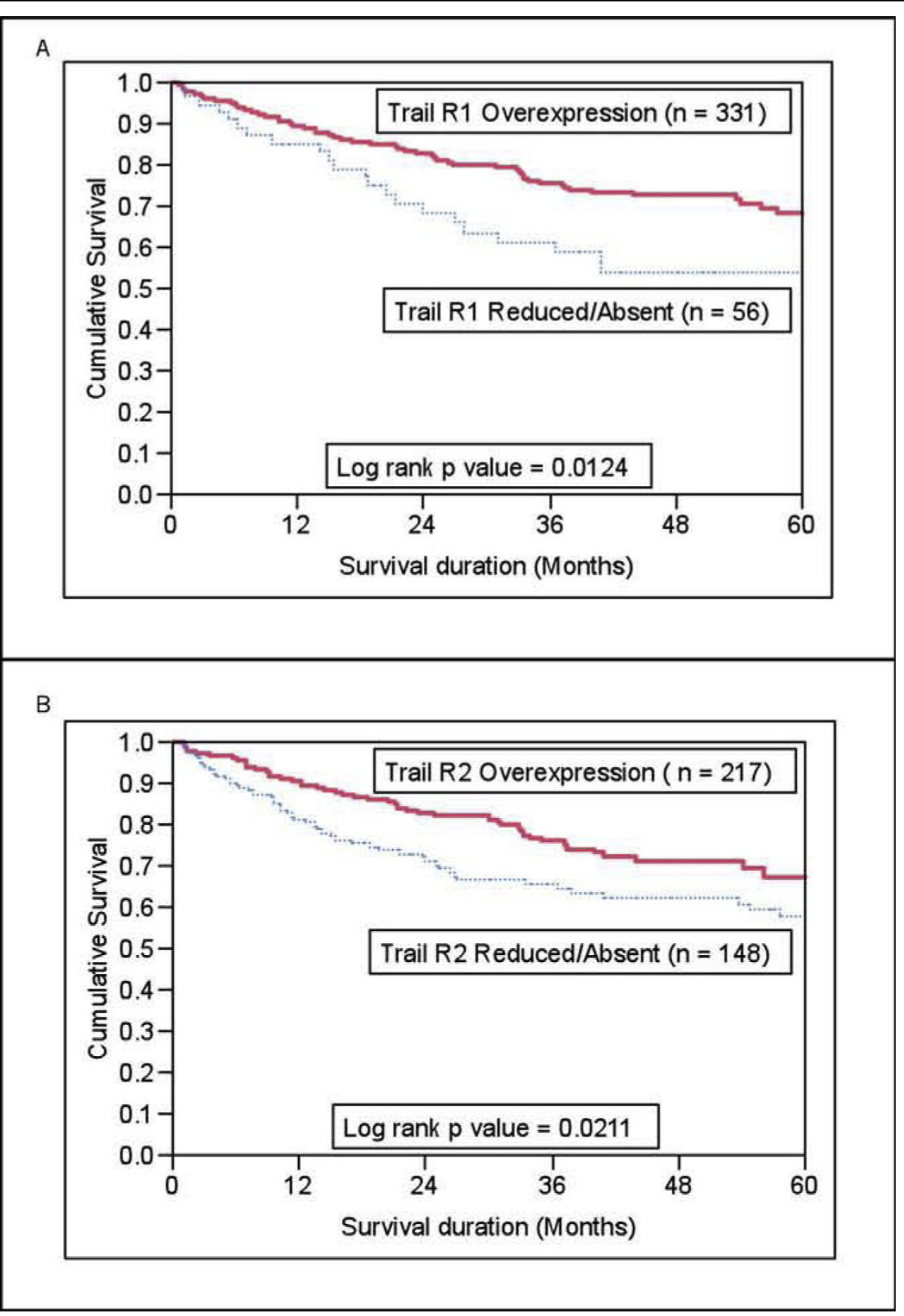

Figure 5 (A) Kaplan Meier survival analysis in CRC patients with over expression of Trail R1 had a better overall survival of $68.1 \%$ at 5 years as compared to $\mathbf{5 3 . 9 \%}$ with reduced TRAIL-R1 expression $(\mathbf{p}=\mathbf{0 . 0 1 2 4})$. (B) CRC patients Trail R2 also showed a better overall survival as of $67.3 \%$ compared to $57.6 \%$ with reduced TRAIL-R2 expression ( $p=0.0211)$.

FLIP $_{\mathrm{L}}$, (the long form of FLICE inhibitory protein) but not TRAIL-R1 or TRAIL-R2, was an independent prognostic factor for shorter disease free survival. In an attempt to explain these conflicting results of TRAIL and its pro-apoptotic receptors in CRC, we offer the following explanations: a) differences and heterogeneity in samples studied: sample size, ethnic differences, different
Stage groups, tumor site- colon or rectal tumors, type of treatment- surgery and/or chemo/radiotherapy; b) differences in scoring system could be another important reason for this difference. The varied effects of TRAIL signaling could be also attributed to the following factors: TRAIL resistance due to presence of decoy receptors [11], number, type and functionality of TRAIL 
Table 3 TRAIL-R1 expression: Cox regression analysis for overall survival of patients with colorectal carcinoma

\begin{tabular}{lllll}
\hline & UNIVARIATE & & MULTIVARIATE \\
\cline { 2 - 5 } Clinical Parameters & Risk Ratio (95\% CI) & p value & Risk Ratio (95\% Cl) & p value \\
\hline Age: Above $=50$ & $1.17(0.80-1.74)$ & 0.4306 & $1.40(0.86-2.33)$ & 0.1755 \\
Sex: Male & $1.10(0.76-1.59)$ & 0.6084 & $1.18(0.75-1.87)$ & 0.4589 \\
Stage: III-IV & $7.26(4.34-13.03)$ & $<0.0001$ & $6.56(3.67-12.78)$ & $<0.0001$ \\
Grade: Poorly differentiated & $1.41(0.90-2.14)$ & 0.1307 & $3.61(1.72-6.80)$ & 0.0014 \\
MSI status: MSI-L/S & $2.04(1.14-4.05)$ & 0.0149 & $1.90(0.95-4.37)$ & 0.0713 \\
Histology: Adenocarcinoma & $1.14(0.67-2.10)$ & 0.6499 & $2.28(0.93-5.43)$ & 0.0695 \\
TRAIL-R1: Low expression & $1.18(1.11-2.83)$ & 0.0196 & $1.84(1.10-3.02)$ & 0.0273 \\
\hline
\end{tabular}

$\mathrm{Cl}=$ confidence interval

receptors [7,12] and intracellular anti apoptotic molecules like c-FLIP [35], IAP [36], Mcl-1 [37] and bcl2 [38].

Although TRAIL-R1 lost its statistical significance when included as a prognostic marker in multivariate analysis with p27 and KRAS4A (see Additional File 1 Table S2), this does not argue against the biological role of TRAIL-R1 in CRC as much as it reflects that p27 and KRAS4A are a more powerful predictor of clinical outcome of CRC than TRAIL-R1 expression. We can hypothesize that the TRAIL-R1 functions most effectively in the cells which show co-expression of p2 $7^{\text {kip } 1}$ in concordance with an earlier study [39]. Despite some studies that show a role of Ras signaling pathway in modulating the TRAIL system, studies on the KRAS isoforms - KRAS4A and KRAS 4B are lacking. Alternate approaches to modulate the expression of KRAS isoforms, a greater understanding of the role(s) that each oncoprotein plays in malignant transformation, including the signal transduction pathways affected, is crucial in the development of therapeutic approaches in cancer treatment, which include the use of drugs that target isoform-specific post-translational modifications [40] and of antisense oligonucleotides to modulate alternative splicing [41].

Oncogenic mutations such as ras may enhance expression of TRAIL receptors; potentially sensitizing these tumors to TRAIL based therapies [19-21]. TRAIL-based therapeutic strategies using TRAIL agonists could be used in cases of human colon cancers bearing RAS mutations. In a small cohort of $51 \mathrm{CRC}$, Oikonomou E et al. [42] have reported a much lower incidence of KRASG12/13 mutations(10\%) and have concluded that there is clear correlation between these mutations(KRAS and BRAF) and upregulation of TRAIL-R1 and TRAILR2. Despite lack of statistical significance they have concluded that CRC with mutations in KRAS or BRAF gene had significantly upregulated both TRAIL death receptors. In our earlier study [43] KRAS gene mutations were seen in 80/285 CRC (28.1\%) and were an independent prognostic marker for poor survival. Interestingly we have observed a significantly higher expression of TRAIL-R2 ( $\mathrm{p}=0.0481)$ in CRC subgroup lacking KRAS mutations(75.5\%) as compared to the CRC subgroup with KRAS mutations(61.1\%). In view of the recent findings of KRAS mutations and PIK3CA mutations contributing to resistance to EGFR inhibitors like Cetuximab, $[44,45]$ a better understanding of the TRAIL system with context to KRAS mutations might be useful. The KRAS gene has two alternative fourth exon variants that result from differential splicing and activating mutations affect both isoforms [46-48]. Studies in animals indicate that KRAS4A promotes apoptosis while KRAS4B inhibits it, and KRAS4B promotes differentiation [49,50]. In our study [43], KRAS 4A a pro apoptotic isoform, in particular was found to be an independent prognostic marker for better survival in all CRC patients. Even in the CRC subgroup lacking KRAS mutations KRAS4A was associated with better survival. Furthermore, we have observed a highly significant association of KRAS4A and both the TRAIL receptors: TRAIL-R1(p < $0.0001)$ and TRAIL-R2 $(\mathrm{p}<0.0001)$. Considering the tight linkage between TRAIL-R1 and KRAS4A future studies should be conducted to understand the association between these markers.

In summary, our study shows high TRAIL-R1 expression to be an independent prognostic marker for better survival in colorectal cancer. High TRAIL-R1 or TRAILR2 expression was associated with a less aggressive phenotype characterized by early AJCC stage, welldifferentiated tumors, microsatellite stable cancers, absence of KRAS mutations and expression of pro apoptotic molecules: KRAS4A, p27 $7^{\text {kip } 1}$ and cleaved caspase 3. Further work is needed to elucidate the biological significance of high TRAIL-R1 expression and better outcome, and to establish the association between TRAIL-R1 expression and response to therapy that targets this receptor. The biological effects of TRAIL in CRC models, its enhancement of chemosensitivity with standard chemotherapeutic agents and the effect of endogenous TRAIL receptor levels on survival make TRAIL an extremely attractive therapeutic target. 


\section{Materials and methods}

\section{Patient selection and tissue microarray construction}

Four hundred forty eight patients with CRC diagnosed between 1990 and 2006 were selected from King Faisal Specialist Hospital and Research Centre. All CRC, 24 adenomas and 229 adjacent normal colorectal mucosa were analyzed in a tissue microarray format. Clinical and histopathological data were available for all these patients. Colorectal Unit, Department of Surgery, provided long-term follow-up data. From our cohort of 448 patients treatment details were available for 310 patients:220 patients received adjuvant therapy; 90 were treated by surgery alone and 138 patients were excluded as we could not retrieve treatment details. Patients with colon cancer underwent surgical colonic resection and those with rectal cancer underwent anterior resection or abdominoperineal resection. All node-positive colon cancers received 5-fluorouracil-based adjuvant chemotherapy. A vast majority of the rectal cancers received radiotherapy alone or chemoradiotherapy prior to surgery, followed by adjuvant chemotherapy after surgery. Fixation of tissues was done overnight with $10 \%$ neutral buffered formalin at the Pathology Laboratory of King Faisal Specialist Hospital and Research Centre, Riyadh. Tissue microarrays were constructed from formalin-fixed, paraffin-embedded colorectal carcinoma specimens as described previously [51]. One pathologist (PB) reviewed all tumors for grade and histological subtype. Institutional Review Board (IRB) of the King Faisal Specialist Hospital \& Research Centre approved the study.

\section{Immunohistochemistry (IHC)}

Tissue microarray slides were processed and stained manually. The streptavidin-biotin peroxidase technique with diaminobenzidine as chromogen was applied. For antigen retrieval, Dako Target Retrieval Solution was used at a pH of 6 for TRAIL-R1 and $\mathrm{pH}$ of 9 for TRAIL-R2 was used, and the slides were microwaved at 750W for 5 minutes and then at $250 \mathrm{~W}$ for 30 minutes. Primary antibodies used, their dilutions, and incidences are listed in Additional File 1 Table S5. The specificity of these antibodies for TRAIL and its receptors has been previously assessed by immunohistochemistry $[28,52]$, or by Western blot [53]. Endogenous peroxidase activity was quenched using $3 \%$ hydrogen peroxidase. Endogenous biotin was blocked and all slides were counterstained with hematoxylin, dehydrated, cleared, and cover slipped with premount. Only fresh cut slides were stained simultaneously to minimize the influence of slide ageing and maximize repeatability and reproducibility of the experiment. As controls, we used a tissue microarray control block comprising multiple cores from normal tissue from various sites, common epithelial cancers and colon cancer cell lines. Omission of the primary antibody also served as a negative control for TRAIL, TRAIL-R1 and -R2 staining.

\section{Immunohistochemistry Assessment}

TRAIL-R1, TRAIL-R2 and TRAIL expression was categorized by doing an $\mathrm{H}$ score $[54,55]$. Each tissue microarray spot was assigned an intensity score from $0-3\left(\mathrm{I}_{0}\right.$, $\left.\mathrm{I}_{1-3}\right)$ and proportion of the tumor staining for that intensity was recorded as $5 \%$ increments from a range of 0 $100\left(\mathrm{P}_{0}, \mathrm{P}_{1-3}\right)$. A final $\mathrm{H}$ score (range $\left.0-300\right)$ was obtained by adding the sum of scores obtained for each intensity and proportion of area stained $\left(\mathrm{H}\right.$ score $=\mathrm{I}_{1 \mathrm{X}} \mathrm{P}_{1}+\mathrm{I}_{2} \mathrm{XP}_{2}$ $+\mathrm{I}_{3} \mathrm{XP}_{3}$ ). CRCs were grouped into two groups based on $\mathrm{X}$-tile plots for TRAIL-R1: one with complete absence or reduced staining $(\mathrm{H}$ score $=0-110)$ and the other group showed over expression $(\mathrm{H}$ score $>110)$ depending on the $\mathrm{H}$ score. Similarly, X-tile plots were used to stratify the CRC cases into two groups for TRAIL-R2 and TRAIL. X-tile plots were constructed for assessment of biomarker and optimization of cut off points based on outcome as has been described earlier [56,57]. For cleaved caspase- 3 expression, we used the antibody clone C5A-1 from Cell signalling technologies as described previously [43]. CRCs were grouped into two groups based on X-tile plots: one with complete absence or reduced staining ( $\mathrm{H}$ score $=0-9$ for low cleaved caspase3); and the other group showed over expression $(\mathrm{H}$ score $>9$ for high cleaved caspase 3). Grading of p27 nuclear protein staining was based on proportion or percentage of cell nuclei staining and was semi quantified as high or low. Nuclear protein expression of epithelial cells only was scored as high if $50 \%$ or more of the nuclei were stained or low if $<50 \%$ were stained as described previously [58]. This scoring criteria has been used earlier [59].

\section{Mutational analysis of the KRAS gene}

KRAS mutations were done as described earlier [43]. Briefly the step-down cycling condition was used for the detection of exon 1 mutation of the KRAS gene. After 10 minutes denaturing at $95^{\circ} \mathrm{C}$, the PCR was run with each temperature for $1 \mathrm{~min}$ at five step-down steps, for two cycles each. The denaturing temperature was $95^{\circ} \mathrm{C}$ and the extension temperature was $72^{\circ} \mathrm{C}$ for each step, with an annealing temperature of $66^{\circ} \mathrm{C}, 64^{\circ}$ $\mathrm{C}, 62^{\circ} \mathrm{C}, 60^{\circ} \mathrm{C}$, and $58^{\circ} \mathrm{C}$ from the first to the last step. The PCR was finally run at $95^{\circ} \mathrm{C}, 58^{\circ} \mathrm{C}$, and $72^{\circ} \mathrm{C}$, each for $1 \mathrm{~min}$ for 35 cycles, followed by an elongation at $72^{\circ} \mathrm{C}$ for $5 \mathrm{~min}$. The PCR products were subsequently subjected to direct sequencing PCR with BigDye terminator V 3.0 cycle sequencing reagents (Applied 
Biosystems, Foster City, CA, USA). The samples were finally analysed on an ABI PRISM 3100xl Genetic Analyzer (Applied Biosystems).

\section{Microsatellite instability}

Allelic imbalances were measured by performing microsatellite analysis on all matched normal and tumor tissue by PCR amplification as described previously [60]. A reference panel of five pairs of microsatellite primers, comprising two mononucleotide microsatellites (BAT25, BAT26) and three dinucleotide microsatellites (DS123, D5S346 and D17S250) were used to determine tumor MSI status. Multiplex PCR was performed in a total volume of $25 \mathrm{ml}$ using $50 \mathrm{ng}$ of genomic DNA, $2.5 \mathrm{ml}$ 10 Taq buffer, $1.5 \mathrm{ml} \mathrm{MgCl} 2(25 \mathrm{mM}), 10 \mathrm{pmol}$ of fluorescent-labeled primers, $0.05 \mathrm{ml} \mathrm{dNTP}(10 \mathrm{mM})$ and $0.2 \mathrm{ml}$ Taq polymerase $(1 \mathrm{U} \mathrm{ml} 1$ ) (all reagents were from Qiagen Inc., Valencia, CA, USA). PCR was performed using an MJ Research PTC-200 thermocycler. The PCR conditions were as follows: after an initial 10 min denaturation step at $951 \mathrm{C}, 40$ amplification cycles were performed consisting of $40 \mathrm{~s}$ at $951 \mathrm{C}, 40 \mathrm{~s}$ at 54 $1 \mathrm{C}$ and a 1 min elongation step at $721 \mathrm{C}$. Amplification was completed with a final extension step at $721 \mathrm{C}$ for 7 $\mathrm{min}$. The fluorescent-labeled products were finally analysed on an ABI PRISM 3100 l Genetic Analyzer (Applied Biosystems, Foster City, CA, USA). Tumors were classified as MSI if at least two or more markers out of the five were unstable and as MSS if only one or none of the markers was unstable.

\section{Statistical Analysis}

The JMP8 (SAS Institute, Inc., Cary, NC) software package was used for data analyses. Survival curves were generated using the Kaplan-Meier method, with significance evaluated using the Mantel-Cox log-rank test. Risk ratio (relative risk for death) was calculated using the Cox Proportional Hazard model in both univariate and multivariate analyses. Comparisons between groups were made with the paired Student's t-test. Chi-square tests were used to examine relationship between nominal variables. The limit of significance for all analyses was defined as a p-value of 0.05 .

\section{Additional material}

Additional file 1: Additional file 1. Table S1. Clinico-pathological characteristics and TRAIL expression in patients with colorectal carcinoma. Table S2. Cox regression analysis for overall survival of colorectal carcinoma patients: TRAIL-R1, KRAS4A and p27 $7^{\mathrm{kip} 1}$. Table S3. Trail-R1 \& R2 co-expression: Cox regression analysis for overall survival of patients with colorectal carcinoma. Table S4. Trail R1 in Adjuvant treated Group: Cox regression analysis for overall survival of patients with colorectal carcinoma. Table S5. Antibodies used for tissue micro array Immunohistochemical analysis.
Additional file 2: Additional file 2. Prognostic significance of TRAlL-R1 \& TRAIL-R2 in early and late stage CRC and Kaplan Meier survival analysis. [A] In the early Stage subgroup (I and II) CRC patients TRAIL-R1

expression was not associated with prognostic outcome $(p=0.4703)$. [B] In the advanced Stage subgroup(III and IV) CRC patients with over expression of TRAIL-R1 $(n=157)$ had a better overall survival of $48.8 \%$ at 5 years as compared to $26.0 \%$ with reduced TRAIL-R1 expression $(n=30$; $p=0.0060$ ). [C] In the early Stage subgroup (I and II) CRC patients TRAILR2 expression was not associated with prognostic outcome $(p=0.5613)$. [D] In the advanced Stage subgroup(III and IV) CRC patients with over expression of TRAIL-R2 $(n=112)$ had a better overall survival of $50.0 \%$ at 5 years as compared to $35.2 \%$ with reduced TRAIL-R2 expression $(n=70$; $p=0.0263$.

Additional file 3: Additional file 3. Prognostic significance of TRAlL-R1 \& R2 in CRC with Stage II and III and Kaplan Meier survival analysis. [A] In the Stage subgroup(II and III) CRC patients with over expression of TRAIL$R 1(n=226)$ had a better overall survival of $67.6 \%$ at 5 years as compared to $63.1 \%$ with reduced TRAIL-R1 expression ( $n=41 ; p=0.2508$ ). [B] In the Stage subgroup(II and III) CRC patients with over expression of TRAIL$R 2(n=149)$ had a better overall survival of $71.3 \%$ at 5 years as compared to $57.3 \%$ with reduced TRAIL-R2 expression ( $n=105 ; p=0.0088$ ).

Additional file 4: Additional file 4. Prognostic significance of coexpression of TRAlL receptors: TRAIL-R1 and TRAIL-R2 in CRC and Kaplan Meier survival analysis. The CRC subgroup with overexpression of TRAILR1 and TRAIL-R2 $(n=191)$ had a better overall survival of $69.5 \%$ at 5 years as compared to Reduced TRAlL-R1 and TRAIL-R2 expression of $57.9 \%(n=145 ; p=0.0107)$.

Additional file 5: Additional file 5. Prognostic significance of TRAIL-R1 \& TRAIL-R2 in CRC based on adjuvant therapy and Kaplan Meier survival analysis. [A] CRC patients with over expression of TRAIL-R1 in adjuvant treated group had a better overall survival of $70.6 \%$ at 5 years as compared to $48.4 \%$ with reduced TRAIL-R1 expression $(n=203 ; p=$ 0.0033). [B] In the non-adjuvant treated group TRAIL-R1 expression was not associated with prognostic outcome $(p=0.8801)$. [C] CRC patients with over expression of TRAIL-R2 in adjuvant treated had a better overall survival of $73.5 \%$ at 5 years as compared to $46.5 \%$ with reduced TRAIL-R2 expression ( $n=168 ; p=0.0998)$. [D] In the non-adjuvant treated group TRAlL-R2 expression was not associated with prognostic outcome $(p=$ $0.8069)$.

\section{Acknowledgements}

We thank Valorie Balde and Hassan Al Dossarie for their skilful technical assistance.

\section{Author details}

'Department of Human Cancer Genomic Research, MBC 98-16,Research Centre at KFNCCC, King Faisal Specialist Hospital and Research Centre,PO Box 3354, Riyadh 11211,Kingdom of Saudi Arabia. 'Department of Pathology, King Faisal Specialist Hospital and Research Centre,PO Box 3354, Riyadh 11211, Kingdom of Saudi Arabia. ${ }^{3}$ Department of Colorectal Surgery, King Faisal Specialist Hospital and Research Centre,PO Box 3354, Riyadh 11211, Kingdom of Saudi Arabia.

\section{Authors' contributions}

PB designed research, performed experiments, analyzed data, and wrote the paper; SP performed validation experiments and helped in writing the paper; JA performed experiments and analyzed data; ZQ \& TG collected and analyzed data; performed statistical analysis FA provided archival pathology material, review of histopathology slides; NA, AA, LAH and SA provided fresh tissue samples, clinical data and reviewed the manuscript, SU analyzed data and helped in writing the paper; KSA designed research, analyzed data, and wrote the paper.

All authors read and approved the final manuscript.

\section{Competing interests}

The authors declare that they have no competing interests. 
Received: 11 February 2010 Accepted: 30 July 2010

Published: 30 July 2010

\section{References}

1. Al-Eid HS AS: Cancer Incidence Report Saudi Arabia 1999-200. King Faisal Specialist Hospital and Research Centre 2004, May 2004.

2. Oldenhuis CN, Oosting SF, Gietema JA, de Vries EG: Prognostic versus predictive value of biomarkers in oncology. Eur J Cancer 2008, 44:946-953.

3. Lowe SW, Lin AW: Apoptosis in cancer. Carcinogenesis 2000, 21:485-495.

4. Nagata S: Apoptosis by death factor. Cell 1997, 88:355-365.

5. Ghobrial IM, Witzig TE, Adjei AA: Targeting apoptosis pathways in cancer therapy. CA Cancer J Clin 2005, 55:178-194.

6. Qiao L, Wong BC: Targeting apoptosis as an approach for gastrointestinal cancer therapy. Drug Resist Updat 2009, 12:55-64.

7. LeBlanc HN, Ashkenazi A: Apo2L/TRAIL and its death and decoy receptors. Cell Death Differ 2003, 10:66-75.

8. Pukac L, Kanakaraj P, Humphreys R, Alderson R, Bloom M, Sung C Riccobene T, Johnson R, Fiscella M, Mahoney A, et al: HGS-ETR1, a fully human TRAIL-receptor 1 monoclonal antibody, induces cell death in multiple tumour types in vitro and in vivo. Br J Cancer 2005, 92:1430-1441.

9. Martin JH, Potthoff A, Ledig S, Cornberg M, Jandl O, Manns MP, Kubicka S, Flemming P, Athmann C, Beil W, Wagner S: Effect of H. pylori on the expression of TRAIL, FasL and their receptor subtypes in human gastric epithelial cells and their role in apoptosis. Helicobacter 2004, 9:371-386.

10. Kuraoka K, Matsumura S, Sanada Y, Nakachi K, Imai K, Equchi H, Matsusaki K, Oue N, Nakayama H, Yasui W: A single nucleotide polymorphism in the extracellular domain of TRAIL receptor DR4 at nucleotide 626 in gastric cancer patients in Japan. Oncol Rep 2005, 14:465-470.

11. Pan G, Ni J, Wei YF, Yu G, Gentz R, Dixit VM: An antagonist decoy receptor and a death domain-containing receptor for TRAIL. Science 1997, 277:815-818

12. Sheridan JP, Marsters SA, Pitti RM, Gurney A, Skubatch M, Baldwin D, Ramakrishnan L, Gray CL, Baker K, Wood WI, et al: Control of TRAILinduced apoptosis by a family of signaling and decoy receptors. Science 1997, 277:818-821.

13. Bodmer JL, Holler N, Reynard S, Vinciguerra P, Schneider P, Juo P, Blenis J, Tschopp J: TRAIL receptor-2 signals apoptosis through FADD and caspase-8. Nat Cell Biol 2000, 2:241-243.

14. Zhang XD, Franco A, Myers K, Gray C, Nguyen T, Hersey P: Relation of TNFrelated apoptosis-inducing ligand (TRAIL) receptor and FLICE-inhibitory protein expression to TRAlL-induced apoptosis of melanoma. Cancer Res 1999, 59:2747-2753.

15. Pai SI, Wu GS, Ozoren N, Wu L, Jen J, Sidransky D, El-Deiry WS: Rare loss-offunction mutation of a death receptor gene in head and neck cancer. Cancer Res 1998, 58:3513-3518.

16. Lee SH, Shin MS, Kim HS, Lee HK, Park WS, Kim SY, Lee JH, Han SY, Park JY, Oh RR, et al: Alterations of the DR5/TRAIL receptor 2 gene in non-small cell lung cancers. Cancer Res 1999, 59:5683-5686.

17. Lee SH, Shin MS, Kim HS, Lee HK, Park WS, Kim SY, Lee JH, Han SY, Park JY, Oh RR, et al: Somatic mutations of TRAIL-receptor 1 and TRAIL-receptor 2 genes in non-Hodgkin's lymphoma. Oncogene 2001, 20:399-403.

18. Shin MS, Kim HS, Lee SH, Park WS, Kim SY, Park JY, Lee JH, Lee SK, Lee SN, Jung SS, et al: Mutations of tumor necrosis factor-related apoptosisinducing ligand receptor 1 (TRAIL-R1) and receptor 2 (TRAIL-R2) genes in metastatic breast cancers. Cancer Res 2001, 61:4942-4946.

19. Wang Y, Engels IH, Knee DA, Nasoff M, Deveraux QL, Quon KC: Synthetic lethal targeting of MYC by activation of the DR5 death receptor pathway. Cancer Cell 2004, 5:501-512.

20. Nesterov A, Nikrad M, Johnson T, Kraft AS: Oncogenic Ras sensitizes normal human cells to tumor necrosis factor-alpha-related apoptosisinducing ligand-induced apoptosis. Cancer Res 2004, 64:3922-3927.

21. Drosopoulos KG, Roberts ML, Cermak L, Sasazuki T, Shirasawa S, Andera L, Pintzas A: Transformation by oncogenic RAS sensitizes human colon cells to TRAIL-induced apoptosis by up-regulating death receptor 4 and death receptor 5 through a MEK-dependent pathway. J Biol Chem 2005, 280:22856-22867.

22. Chin L, Tam A, Pomerantz J, Wong M, Holash J, Bardeesy N, Shen Q, O'Hagan R, Pantginis J, Zhou H, et al: Essential role for oncogenic Ras in tumour maintenance. Nature 1999, 400:468-472.
23. Li W, Zhu T, Guan KL: Transformation potential of Ras isoforms correlates with activation of phosphatidylinositol 3-kinase but not ERK. J Biol Chem 2004, 279:37398-37406.

24. Plattner R, Gupta S, Khosravi-Far R, Sato KY, Perucho M, Der CJ, Stanbridge EJ: Differential contribution of the ERK and JNK mitogenactivated protein kinase cascades to Ras transformation of HT1080 fibrosarcoma and DLD-1 colon carcinoma cells. Oncogene 1999, 18:1807-1817.

25. Hoshino R, Chatani Y, Yamori T, Tsuruo T, Oka H, Yoshida O, Shimada Y, Arii S, Wada H, Fujimoto J, Kohno M: Constitutive activation of the 41-/43$\mathrm{kDa}$ mitogen-activated protein kinase signaling pathway in human tumors. Oncogene 1999, 18:813-822.

26. Strater J, Hinz U, Walczak $H$, Mechtersheimer G, Koretz K, Herfarth C, Moller $\mathrm{P}$, Lehnert T: Expression of TRAIL and TRAIL receptors in colon carcinoma: TRAIL-R1 is an independent prognostic parameter. Clin Cancer Res 2002, 8:3734-3740.

27. Koornstra JJ, Jalving M, Rijcken FE, Westra J, Zwart N, Hollema H, de Vries EG, Hofstra RW, Plukker JT, de Jong S, Kleibeuker JH: Expression of tumour necrosis factor-related apoptosis-inducing ligand death receptors in sporadic and hereditary colorectal tumours: potential targets for apoptosis induction. European Journal of Cancer 2005, 41:1195-1202.

28. Granci V, Bibeau F, Kramar A, Boissiere-Michot F, Thezenas S, Thirion A, Gongora C, Martineau P, Del Rio M, Ychou M: Prognostic significance of TRAIL-R1 and TRAIL-R3 expression in metastatic colorectal carcinomas. Eur $J$ Cancer 2008, 44:2312-2318.

29. Ullenhag GJ, Mukherjee A, Watson NF, Al-Attar AH, Scholefield JH, Durrant LG: Overexpression of FLIPL is an independent marker of poor prognosis in colorectal cancer patients. Clin Cancer Res 2007, 13:5070-5075.

30. van Geelen CM, Westra JL, de Vries EG, Boersma-van Ek W, Zwart N, Hollema H, Boezen HM, Mulder NH, Plukker JT, de Jong S, et al: Prognostic significance of tumor necrosis factor-related apoptosis-inducing ligand and its receptors in adjuvantly treated stage III colon cancer patients. $J$ Clin Oncol 2006, 24:4998-5004.

31. Koornstra JJ, Kleibeuker JH, van Geelen CM, Riicken FE, Hollema H, de Vries EG, de Jong S: Expression of TRAIL (TNF-related apoptosis-inducing ligand) and its receptors in normal colonic mucosa, adenomas, and carcinomas. J Pathol 2003, 200:327-335.

32. Wiley SR, Schooley K, Smolak PJ, Din WS, Huang CP, Nicholl JK, Sutherland GR, Smith TD, Rauch C, Smith CA, et al: Identification and characterization of a new member of the TNF family that induces apoptosis. Immunity 1995, 3:673-682.

33. Pitti RM, Marsters SA, Ruppert S, Donahue CJ, Moore A, Ashkenazi A: Induction of apoptosis by Apo-2 ligand, a new member of the tumor necrosis factor cytokine family. J Biol Chem 1996, 271:12687-12690.

34. Hague A, Hicks DJ, Hasan F, Smartt H, Cohen GM, Paraskeva C, MacFarlane M: Increased sensitivity to TRAlL-induced apoptosis occurs during the adenoma to carcinoma transition of colorectal carcinogenesis. Br J Cancer 2005, 92:736-742.

35. Irmler $M$, Thome $M$, Hahne $M$, Schneider $P$, Hofmann $K$, Steiner $V_{t}$ Bodmer JL, Schroter M, Burns K, Mattmann C, et al: Inhibition of death receptor signals by cellular FLIP. Nature 1997, 388:190-195.

36. Deveraux QL, Takahashi R, Salvesen GS, Reed JC: X-linked IAP is a direct inhibitor of cell-death proteases. Nature 1997, 388:300-304.

37. Wirth T, Kuhnel F, Fleischmann-Mundt B, Woller N, Djojosubroto M, Rudolph KL, Manns M, Zender L, Kubicka S: Telomerase-dependent virotherapy overcomes resistance of hepatocellular carcinomas against chemotherapy and tumor necrosis factor-related apoptosis-inducing ligand by elimination of Mcl-1. Cancer Res 2005, 65:7393-7402.

38. Fulda S, Meyer E, Debatin KM: Inhibition of TRAIL-induced apoptosis by BCl-2 overexpression. Oncogene 2002, 21:2283-2294.

39. Garofalo M, Quintavalle C, Di Leva G, Zanca C, Romano G, Taccioli C, Liu CG, Croce CM, Condorelli G: MicroRNA signatures of TRAIL resistance in human non-small cell lung cancer. Oncogene 2008, 27:3845-3855.

40. Adjei AA: Blocking oncogenic Ras signaling for cancer therapy. J Natl Cancer Inst 2001, 93:1062-1074

41. Sazani P, Kole R: Therapeutic potential of antisense oligonucleotides as modulators of alternative splicing. J Clin Invest 2003, 112:481-486.

42. Oikonomou E, Kosmidou V, Katseli A, Kothonidis K, Mourtzoukou D, Kontogeorgos G, Andera L, Zografos G, Pintzas A: TRAIL receptor 
upregulation and the implication of KRAS/BRAF mutations in human colon cancer tumors. Int J Cancer 2009, 125:2127-2135.

43. Abubaker J, Bavi P, Al-Haqawi W, Sultana M, Al-Harbi S, Al-Sanea N, Abduljabbar A, Ashari LH, Alhomoud S, Al-Dayel F, et al: Prognostic significance of alterations in KRAS isoforms KRAS-4A/4B and KRAS mutations in colorectal carcinoma. J Pathol 2009, 219:435-445.

44. Lievre A, Bachet JB, Le Corre D, Boige V, Landi B, Emile JF, Cote JF, Tomasic $\mathrm{G}$, Penna $\mathrm{C}$, Ducreux $\mathrm{M}$, et al: KRAS mutation status is predictive of response to cetuximab therapy in colorectal cancer. Cancer Res 2006 , 66:3992-3995.

45. Sartore-Bianchi A, Martini M, Molinari F, Veronese S, Nichelatti M, Artale S, Di Nicolantonio F, Saletti P, De Dosso S, Mazzucchelli L, et al: PIK3CA mutations in colorectal cancer are associated with clinical resistance to EGFR-targeted monoclonal antibodies. Cancer Res 2009, 69:1851-1857.

46. Malumbres M, Barbacid M: RAS oncogenes: the first 30 years. Nat Rev Cancer 2003, 3:459-465.

47. Capon DJ, Seeburg PH, McGrath JP, Hayflick JS, Edman U, Levinson AD, Goeddel DV: Activation of Ki-ras2 gene in human colon and lung carcinomas by two different point mutations. Nature 1983, 304:507-513.

48. Welman A, Burger MM, Hagmann J: Structure and function of the Cterminal hypervariable region of $\mathrm{K}$-Ras $4 \mathrm{~B}$ in plasma membrane targetting and transformation. Oncogene 2000, 19:4582-4591.

49. Plowman SJ, Arends MJ, Brownstein DG, Luo F, Devenney PS, Rose L, Ritchie AM, Berry RL, Harrison DJ, Hooper ML, Patek CE: The K-Ras 4A isoform promotes apoptosis but does not affect either lifespan or spontaneous tumor incidence in aging mice. Exp Cell Res 2006, 312:16-26.

50. Patek CE, Arends MJ, Rose L, Luo F, Walker M, Devenney PS, Berry RL, Lawrence NJ, Ridgway RA, Sansom OJ, Hooper ML: The pro-apoptotic KRas $4 \mathrm{~A}$ proto-oncoprotein does not affect tumorigenesis in the ApcMin/ + mouse small intestine. BMC Gastroenterol 2008, 8:24.

51. Bavi P, Jehan Z, Atizado V, Al-Dossari H, Al-Dayel F, Tulbah A, Amr SS, Sheikh SS, Ezzat A, El-Solh H, et al: Prevalence of fragile histidine triad expression in tumors from saudi arabia: a tissue microarray analysis. Cancer Epidemiol Biomarkers Prev 2006, 15:1708-1718.

52. Sanlioglu AD, Dirice E, Elpek O, Korcum AF, Balci MK, Omer A, Griffith TS, Sanlioglu S: High levels of endogenous tumor necrosis factor-related apoptosis-inducing ligand expression correlate with increased cell death in human pancreas. Pancreas 2008, 36:385-393.

53. Tomek S, Koestler W, Horak P, Grunt T, Brodowicz T, Pribill I, Halaschek J, Haller G, Wiltschke C, Zielinski CC, Krainer M: Trail-induced apoptosis and interaction with cytotoxic agents in soft tissue sarcoma cell lines. Eur J Cancer 2003, 39:1318-1329.

54. McCarty KS Jr, Miller LS, Cox EB, Konrath J, McCarty KS Sr: Estrogen receptor analyses. Correlation of biochemical and immunohistochemical methods using monoclonal antireceptor antibodies. Arch Pathol Lab Med 1985, 109:716-721.

55. Uddin S, Siraj AK, Al-Rasheed M, Ahmed M, Bu R, Myers JN, Al-Nuaim A, AlSobhi S, Al-Dayel F, Bavi P, et al: Fatty acid synthase and AKT pathway signaling in a subset of papillary thyroid cancers. J Clin Endocrinol Metab 2008, 93:4088-4097.

56. Camp RL, Dolled-Filhart M, Rimm DL: X-tile: a new bio-informatics tool for biomarker assessment and outcome-based cut-point optimization. Clin Cancer Res 2004, 10:7252-7259.

57. McCarthy MM, Sznol M, DiVito KA, Camp RL, Rimm DL, Kluger HM: Evaluating the expression and prognostic value of TRAIL-R1 and TRAILR2 in breast cancer. Clin Cancer Res 2005, 11:5188-5194.

58. Uddin S, Ahmed M, Bavi P, El-Sayed R, Al-Sanea N, AbdulJabbar A, Ashari LH, Alhomoud S, Al-Dayel F, Hussain AR, Al-Kuraya KS: Bortezomib (Velcade) induces p27Kip1 expression through S-phase kinase protein 2 degradation in colorectal cancer. Cancer Res 2008, 68:3379-3388.

59. Shapira M, Ben-Izhak O, Bishara B, Futerman B, Minkov I, Krausz MM, Pagano M, Hershko DD: Alterations in the expression of the cell cycle regulatory protein cyclin kinase subunit 1 in colorectal carcinoma. Cancer 2004, 100:1615-1621.

60. Abubaker J, Bavi P, Al-Harbi S, Ibrahim M, Siraj AK, Al-Sanea N, Abduljabbar A, Ashari LH, Alhomoud S, Al-Dayel F, et al: Clinicopathological analysis of colorectal cancers with PIK3CA mutations in Middle Eastern population. Oncogene 2008, 27:3539-3545. doi:10.1186/1476-4598-9-203

Cite this article as: Bavi et al.: Prognostic significance of TRAIL death receptors in Middle Eastern colorectal carcinomas and their correlation to oncogenic KRAS alterations. Molecular Cancer 2010 9:203.

\section{Submit your next manuscript to BioMed Central and take full advantage of:}

- Convenient online submission

- Thorough peer review

- No space constraints or color figure charges

- Immediate publication on acceptance

- Inclusion in PubMed, CAS, Scopus and Google Scholar

- Research which is freely available for redistribution

Submit your manuscript at www.biomedcentral.com/submit 